\title{
Organizational Factors Associated with Health Worker Protection: A Participatory Mixed-Method Cross-Sectional Analysis in Four Provinces of South Africa
}

Muzimkhulu Zungu ( $\nabla$ MuzimkhuluZ@nioh.ac.za)

National Institute for Occupational Health, a division of the National Health Laboratory Service

Kuku Voyi

University of Pretoria

Nosimilo Mlangeni

National Institute for Occupational Health, a division of the National Health Laboratory Service Saiendhra Moodley

University of Pretoria

Jonathan Ramodike

National Institute for Occupational Health, a division of the National Health Laboratory Service

Nico Claassen

University of Pretoria

Elizabeth Wilcox

University of British Columbia

Nkululeko Thunzi

Sefako Makgatho Health Sciences University

Annalee Yassi

University of British Columbia

Jerry Spiegel

University of British Columbia

Molebogeng Malotle

National Institute for Occupational Health, a division of the National Health Laboratory Service

\section{Research Article}

Keywords: SARS-CoV-2; Occupational safety and health systems; HealthWISE

Posted Date: July 1st, 2021

DOI: https://doi.org/10.21203/rs.3.rs-557415/v1 
License: (c) (i) This work is licensed under a Creative Commons Attribution 4.0 International License. Read Full License 


\section{Abstract}

Background: Health workers, in short supply in many low-and-middle-income countries (LMICs), are at increased risk of SARS-CoV-2 infection during their employment. This study aimed to assess how South Africa, an LMIC, prepared to protect its health workers from SARS-CoV-2.

Methods: This was a participatory mixed method study conducted in four provinces of South Africa. We used a semi-structured questionnaire and a walkthrough survey to collect data on occupational safety and health (OSH) systems in 45 hospitals across four provinces to identify factors associated with health worker protection. Adapting the International Labour Organization (ILO) and World Health Organization (WHO) HealthWISE tool, we compiled compliance scores through walkthrough surveys. For the questionnaire, the participants were provincial OSH managers. For the walkthrough survey, they were frontline health workers, facility managers, and OSH and Infection Prevention and Control (IPC) professionals. We used logistic regression to analyze the relationship between readiness indicators and the actual implementation of protective measures. We also evaluated the association between OSH compliance and hospital infection rates.

Results: We found that health facilities in all four provinces had SARS-CoV-2 plans for the general population but no comprehensive OHS plan for health workers. Province A and D Provincial Department of Health (PDoH) had an OSH SARS-CoV-2 provincial coordinating team and a dedicated budget for occupational health. Province A had an occupational health doctor and an occupational health nurse, while Province B had an occupational health nurse. Province A and D PDoHs had functional OSH committees, and Province D had conducted some health risk assessments specific to SARS-CoV-2. However, none of the assessed health facilities had an acceptable HealthWISE compliance score $(\geq 75 \%)$ due to poor ventilation and inadequate administrative control measures.

While the supply of personal protective equipment (PPE) was adequate, PPE was often not worn properly. Our study found that having an OSH SARS-CoV-2 policy was significantly associated with higher PPE and ventilation scores. In addition, our analysis showed that hospitals with higher compliance scores had significantly lower infection rates (IRR 0.98; $95 \% \mathrm{Cl}: 0.97,0.98)$.

Conclusions: Despite some initial preparedness, greater effort to protect health workers is still warranted. LMICs may need to pay more attention to OSH systems and consider using tools, such as ILO/WHO HealthWISE tool, to protect health workers' health.

\section{Background}

The World Health Organization (WHO) declared severe acute respiratory syndrome coronavirus 2 (SARSCoV-2) a Public Health Emergency of International Concern and subsequently a Global Pandemic on January 30 and March 11, 2020, respectively [1, 2]. As of April 30, 2021, globally, there were 150,110,310 cases and 3,158,792 deaths from coronavirus disease (COVID-19) [3]. South Africa, a low-and-middleincome country (LMIC) in Sub-Saharan Africa, had 1,581,210 cases and 54,350 deaths in the general 
population [4]. The National Institute for Occupational Health $(\mathrm{NIOH})$ in South Africa reported that out of 231,552 COVID-19 hospital admissions recorded up to April 10, 2021, 6,877 (2.9\%) were health workers [5].

Lan et al. reported that health workers-along with other occupations like transport, salesperson, housekeepers, and religious workers-were high-risk occupations, even though their COVID-19 infection rate was lower than other groups and the occurrence time-lagged as a reflection of heightened infection prevention and control (IPC) measures in health settings [6]. Health workers were also among the highest risk occupations for exposure to the previous severe acute respiratory syndrome (SARS) pandemic [7]. They were further identified as a high-risk occupational group in Asian countries during both the SARS and the Middle East respiratory syndrome (MERS) coronavirus outbreaks [8]. Clinicians and those performing aerosol-generating procedures in particular account for a significant proportion of SARS-CoV2 infection and may experience exceptionally high infection incidence following unprotected exposure [9].

There are conflicting reports on the risk of SARS-CoV-2 infection in health workers. Canova et al. reported a low risk of infection of health workers during routine short clinical examination and short physical contact [10]. Folgueira et al. reported 'no statistically significant difference in the proportion of SARS-CoV2 positive polymerase chain reaction (PCR) detection between health workers from high-risk areas involved in close contact with COVID-19 patients in comparison with clerical, administrative, or laboratory personnel without direct contact with patients' [11]. Early reports from China suggested that health workers may be at an increased risk $[12,13]$; the risk is also dependent on whether the health worker performs high-risk work associated with respiratory aerosol production, long work hours and suboptimal hand hygiene [14].

Health workers are an essential component in the six building blocks of a health system as described by WHO [15]. Health workers will continue to be a scarce vital resource in the fight against SARS-CoV-2, especially in LMICs. The WHO estimates a projected shortfall of about 18 million health workers by 2030; this shortfall is even more critical in South East Asia and the African regions [16, 17]. There are international calls for LMICs, especially in South East Asia and the African region, to put in place occupational safety and health (OSH) systems and SARS-CoV-2 IPC measures to protect health workers and guard against the collapse of health services secondary to COVID-19 absenteeism. Additionally, protecting health workers is a matter of social justice for this occupational group, irrespective of the legal obligation to provide a safe work environment or the need for health workers to provide care for others.

South Africa has been preparing for SARS-CoV-2 since early February 2020, mainly to protect its health workers before the upsurge of cases in the southern hemisphere. These interventions rely on a strong $\mathrm{OSH}$ system and possible utilization of affordable and cost-effective OSH tools, such as the joint International Labour Organization (ILO) and WHO's Work Improvement in Health Services (HealthWISE) [18]. Two of HealthWISE's four principles are building on local practices and resources and promoting learning-by-doing. 
An OSH system is a sub-system of a country's overarching health systems; South Africa has a unified health system under the National Department of Health with service delivery in public and private sectors [19]. Service delivery in the public sector is the responsibility of nine provincial departments of health (PDoHs). According to the WHO, a health system comprises six building blocks: leadership/governance (health policy, accountability and transparency, and coordination); financing; health workforce; medical products and technology; information, and service delivery $[15,20]$. Since this model of standardized health system components is not diseases specific, South Africa should have utilized it in assessing the SARS-CoV-2 readiness of the OSH system at a PDoHs level [20]. In South Africa, health and safety committees (HSC) are mandatory under the Occupational Health and Safety Act. However, the effectiveness of these bodies is varied and a matter for continued strengthening [21].

The ILO/WHO HealthWISE is a participatory tool for identifying potential hazards (such as SARS-CoV-2) and implement relevant control measures in LMICs. In the COVID-19 pandemic context, HealthWISE encourages managers and staff to work together to improve SARS-CoV-2 IPC and OSH interventions [18]. South Africa participated in the pilot of the ILO/WHO HealthWISE tool [22]. Its effectiveness in improving OSH in health care facilities has been evaluated previously in South Africa [22], but not in the specific context of protecting health workers against the SARS-CoV-2.

We aimed to explore the extent to which South Africa has been abiding by its legal and social responsibility to protect health workers, a potentially vulnerable workforce by 1 ) assessing the readiness of OSH systems in place to protect health workers from SARS-CoV-2 in four PDoHs using the WHO's health system framework; 2) conducting a health facility assessment for the protection of health workers against SARS-CoV-2 infection based on principles of the ILO and WHO developed HealthWISE tool; and 3) ascertaining the relationship between, on the one hand, the existence of policies and/or easy-to-use tools such as HealthWISE, and, on the other hand, the implementation of concrete OHS programmes and/or protective measures, at the time (April - June), WHO declared had declared a global pandemic.

\section{Methods}

\section{Study design}

We used a cross-sectional study design applying participatory action research (PAR) principles to enable action and empower active participation in strengthening $\mathrm{OSH}[23]$. Our study design and methods were selected to enable interaction between the researchers and participants at all stages, including data collection. We also provided advisory and collective steps for corrective measures where necessary to prevent or halt the spread of SARS-Cov-2 among health workers using an adopted ILO/WHO-developed HealthWISE tool. We ensured that responsibility and decisions necessary for action were shared and acted upon between the research team, managers and health workers. We conducted the research in collaboration with the participants as active partners to promote sustainability in line with both HealthWISE and PAR principles $[18,23]$. This research was part of a larger study, with four different 
components, including a COVID-19 knowledge attitudes and practice survey, in which some of our methods were described [24].

\section{Study setting and population}

The study population included OSH managers (completed the study questionnaires), professionals and health workers (participated in walkthrough survey) from four Provincial Departments of Health. We refer to them as Province A, Province B, Province $C$, and Province D to maintain confidentiality and a culture of 'no blame,' following the principles of the HealthWISE tool. Health workers included managers, OSH, and IPC professionals and other frontline staff from all participating PDoHs.

\section{Sampling}

We premised our study sampling on the operational needs of the participating PDoHs. The participating PDoHs were selected because the South African National Department of Health tasked the researchers to provide them with $\mathrm{OSH}$ technical support. PDoH officials selected a total of 45 health facilities based on operational purposes and perceived risk of SARS-CoV-2. Health workers from the participating health facilities, selected in consultation with hospital management, were $\mathrm{OSH}$ and environmental health professionals, unit managers, and trade union representatives.

\section{Measurement tools and data collection}

We developed an interviewer-driven semi-structured questionnaire based on the WHO building blocks of a health system [15], the ILO Convention 161 [25] and a multi-country OHS survey by Rantanen et al.[26], with closed-ended questions. Two occupational hygienists and two occupational medicine doctors tested the feasibility of the questionnaire. Lastly, we collected data from four PDoHs OSH managers on the SARS-CoV-2 readiness of the provincial governments.

We also used an adapted HealthWISE checklist[18]-incorporating some elements of the CDC guidelines for TB IPC[27]-to conduct a walkthrough assessment of the health facilities. During the walkthrough assessment, the researchers and facility health workers assessed distinct work areas: i) the main passenger and vehicle entrance (staffed by security personnel); ii) accident and emergency area (staffed by frontline health workers including security, administrative clerks, porters, cleaners, nurses and medical doctors); iii) the outpatient department (with similar staff as the accident and emergency area); and iv) the SARS-CoV-2 dedicated wards for suspected and confirmed patients (staffed by specialized nursing, medical and cleaning staff). The assessment focused primarily on the "hierarchy of controls" areas of ventilation, administrative control, and personal protective equipment [28] for SARS-CoV-2. The two data collection tools were tested in an initial pilot with five hospitals from the participating PDoHs in April 2020, while the full PAR was conducted between April 28 and June 15, 2020.

\section{Variables measured}

Variables of interest for the assessment of $\mathrm{OSH}$ readiness included the availability of a policy document to protect health workers, such as an OSH policy or IPC policy specific to the protection of health workers, 
the PDoHs coordination structure, and the availability of occupational medical doctor (OMP) or occupational health nurse $(\mathrm{OHN})$. For the facility assessment, we calculated a total HealthWISE compliance score for each assessed area in the hospital, with a total possible score of 88 per hospital. The total HealthWISE scores were compiled from three categories: administrative control (possible score of 56), ventilation scores (possible score of 16), and PPE control (possible score of 16). Each health facility compliance score was graded according to Acceptable $\geq 75 \%$; Requiring improvement $(74 \%$ $50 \%$ ); and Unacceptable $<50 \%$. We also collected hospital-specific information on infection rates among staff and the total number of employees.

\section{Data management and analysis}

We performed double data entry and analysis on Microsoft Excel. We then imported the files into STATA version 16 (Stata Corp (2017) Stata Statistical Software: Release 15. College Station, TX: StataCorp LLC) for further analysis. Logistic regression was used to model the association between HealthWISE scores (dependent variable) and the likelihood of a PDoH having a COVID-19 OHS policy or IPC policy (independent variable). We calculated the odds ratio and the respective $95 \%$ confidence intervals. A random effect on facility was added to the logistic regression to account for a potential clustering effect, resulting in a generalized linear mixed-effects regression. Finally, we used Poisson regression to study the association between the number of cases at a hospital (dependent variable) and the compliance score (independent variable), offset by the total number of employees at the hospital.

\section{Intervention}

Since our study was PAR, the researchers provided a four-hour training on the data collection tools and the basics of the HealthWISE tool for each participating health facility and provincial department of health. This was followed by immediate data collection and administering of the adapted HealthWISE tool. Whenever the researchers identified gaps, the researchers and health facility personnel took immediate corrective advice and action. This action was followed by technical report briefings to provincial and hospital management on OSH and SARS-CoV-2 interventions for their province and health facility.

\section{Intervention}

Since our study was PAR, the researchers provided a four-hour training on the data collection tools and the basics of the HealthWISE tool for each participating health facility and provincial department of health. This was followed by immediate data collection and administering of the adapted HealthWISE tool. Whenever the researchers identified gaps, the researchers and health facility personnel took immediate corrective advice and action. This action was followed by technical report briefings to provincial and hospital management on OSH and SARS-CoV-2 interventions for their province and health facility.

\section{Results}




\section{Provincial assessment of OSH for health workers' readiness for SARS-CoV-2}

\section{Participant characteristics}

Four PDoHs-representing 170,686 health workers-participated in the OSH readiness assessment. The $\mathrm{OSH}$ directorate represented provinces $\mathrm{A}$ and $\mathrm{B}$. The Employee Health and Wellness directorate and the Department of Public Health Medicine represented Provinces C and D, respectively. By June 12, 2020, the four PDoHs had 3,675 SARS-CoV-2 cumulative cases among health workers (2,670 in Province A, 599 in Province B, 207 in Province C, and 199 in Province D).

\section{Provincial Occupational Health Services readiness for the protection of health workers}

At the time of data collection, all four provinces had a provincial SARS-CoV-2 plan from which they were working, albeit not specific for OSH for health workers. In addition, provinces $\mathrm{A}$ and $\mathrm{C}$ had an IPC policy specific for SARS-CoV-2 in the health sector. Only Provinces A and D had OSH SARS-CoV-2 provincial coordinating teams and a dedicated budget for $\mathrm{OSH}$.

At the PDoH level, only Province A had an occupational medical practitioner. Provinces A and B had an occupational health nurse. All PDoHs had an IPC manager and an environmental health practitioner, except for Province C, which lacked the latter. Only Province A had an occupational hygienist, and only Province $\mathrm{C}$ lacked employee health and wellness professionals. Statutory laws in South Africa require employers to have health and safety representatives and committees, but only Province A and D had functional committees.

At the time of data collection, all PDoHs had provided SARS-CoV-2 training to a proportion of their health workforce. Province A provided the seasonal influenza vaccine to its health workers. Province $D$ had conducted some health risk assessments specific to SARS-CoV-2. Provinces A and D reported having rehabilitation plans for infected and affected health workers and regularly screen them looking for incident cases. All Provinces but Province B provided treatment and mental health services. However, provinces $\mathrm{B}$ and $\mathrm{C}$ did not have adequate personal protective equipment.

All four PDoH reported were collecting SARS-CoV-2 data from their health facilities using a tool (these differed in all the PDoHs). The PDoH reasons for collecting data included reporting to National Government Authorities, including the Department of Health and Department of Employment and Labour, and the Department of Public Service and Administration, the employer of public servants in South Africa. Except for Province D, all the PDoHs indicated that they had a server to store the data, and none of the PDoH had a monitoring and evaluation plan.

\section{Health facility assessment based on principles of the HealthWISE tool}

Health facilities and participants in the HealthWISE walkthrough assessment 
Forty-five health facilities representing 34,192 health workers (i.e. $20 \%$ of the health workforce in the four PDoH studied) participated in the HealthWISE guided health facility SARS-CoV-2 assessment. The health workers who were trained and participated in the HealthWISE walkthrough assessment included: occupational medical practitioners, occupational health nurses, environmental health practitioners, IPC nurses, quality assurance nurses, and hospital managers (medical, nursing managers and finance). In addition, the sample included employee health and wellness practitioners and trade unions. Participation of occupational health doctors, occupational health nurses, EHPs, and IPC nurses depended on whether the hospital had such professionals on their staff establishment. As such, we used this indicator as a proxy for the availability of OSH services in that particular health facility.

\section{HealthWISE walkthrough assessment findings for all facilities}

The main entrance to the health facilities is the first contact between patients and the health facilities. It has a pedestrian gate or door-like structure and boom gate for vehicles which is manned by security guards. The walkthrough (Table 1) observed that the opportunity for close contact between security personnel and pedestrian patients as well as security personnel and drivers of vehicles was highly probable. Both the pedestrians and drivers had to sign in a security booklet; during this period, the opportunity of cross-infection increased due to the proximity of individuals, exchange of pens and booklets, and poor attention to IPC protocols.

While ventilation in the main entrance was adequate for health workers in the outdoors security area, security guard houses were often small and crowded and lacked windows or any other form of ventilation. During the walkthrough, a lack of administrative control was immediately apparent, as there was generally a lack of posters and signs. There were crowded chairs indicative of no social distancing, even in the absence of health workers in the area. The majority of security guards were wearing cloth masks but had them below their noses.

The accident and emergency areas in most health facilities were high-risk with the twenty-four-hour operation. We display the findings of walking through this area in Table 2. Ventilation was a considerable challenge in the majority of assessed health facilities. Natural ventilation was impaired by mostly poor facility design, while mechanical ventilation was not available in many facilities and when available was broken and had a poor maintenance record. In the health facilities assessed early on in the study, we noticed that administrative controls would only be followed and monitored during working hours. Afterhours, there is no extra staff assisting with the enforcement of IPC measures, leading to a lack of implementation and monitoring of IPC measures for evening and night shifts.

In the accident and emergency department, the social distancing of staff was a great challenge due to insufficient space and high patient load. In some of the health facilities assessed, we found that they had or planned to have makeshift working areas using tents in some instances. This arrangement led to overcrowding, more pronounced in urban facilities. Health facilities in rural areas had high patient volumes in the mornings and almost no patients in the afternoons, allowing for social distancing. Health workers across facilities were often found congregating when engaging in administrative work or not 
attending to patients. There were many facilities with small or no rest areas leading to health workers crowding the administrative areas for their paperwork and resting periods. It was, however, concerning that there were very few or no SARS-CoV-2 posters or educational materials in most facilities. Waste management was generally good in the majority of assessed health facilities. The majority of the health workers were wearing the appropriate PPE, and most were wearing it correctly. In a few hospitals, health workers would come to work in their uniform, work with it and return home wearing it.

The findings for the outpatient departments in the assessed health facilities (Table 3) were similar to the accident and emergency department walkthrough. About half of health facilities assessed had some combination of natural and mechanical ventilation, with Province A facilities being most affected by poor ventilation. Social distancing was adhered to by the majority of the patients. Most health facilities aided this by marking brightly and visibly cancelling out some chairs or seating areas and rendering them unavailable for use. Patients standing in queues were assisted with markings of distances of between 1.5 meters and above to maintain social distance. Health workers had no or low access to often small dining and rest areas, leading to poor social distancing. Several health facilities had rearranged the furniture to allow for social distancing. A notable issue was the lack of posters and information on how health workers can protect themselves from being infected with SARS-CoV-2. There was access to water, soap and sanitizers for hand hygiene and proper management of waste from SARS-CoV-2 contaminated materials. On observation, workers were wearing PPE though it varied with a few wearing cloth masks and surgical masks and many using respirators, particularly N95 respirators.

The wards dedicated to suspected and confirmed SARS-CoV-2 patients varied considerably within and between provinces (Table 4). Some facilities did not have these wards or were still in the preparatory stages for these wards (i.e. renovations were taking place). Ventilation in these wards was mechanized and working. However, in Province A, there were a few health facilities with poor ventilation with nonfunctioning mechanical ventilation. In almost all health facilities assessed, the suspected and confirmed SARS-CoV-2 patients were socially distancing or kept in physically separated rooms. Health workers were social distancing in the main, except in a few health facilities in Province A, where we found health workers seated close to the main administration desk area when not attending to patients. Most of the health facilities had set up the furniture to allow for social distancing.

The posters in these wards were not specific for OSH or the protection of health workers, and their placement in the wards was not ideal for easy access by health workers. The facilities had water, soap and sanitizers except for one health facility with no water due to municipality failures for the whole town. Sanitizers, while present, were not strategically placed for easy access by health workers. Waste management was adequate, and health workers were able to discard with ease all contaminated materials. Health workers had access and were wearing PPE correctly with the exception of a few health facilities in Province A. Some health facilities in Province $C$ displayed some elements of best practice as they had a suspect and confirmed SARS-CoV-2 patient ward separate from the rest of the hospital building, and the health workers for that ward were isolated from the rest of the hospital, stayed in accommodation provided by the hospital, and utilized hospital clothing and PPE during their shifts. 
Table 5 presents the individual HealthWISE scores per health facility. The lowest was $14 / 88$, while the highest was 73/88 (median 42, IQR 27-53.5), administrative scores were from 6/56-50/56 (median 28, IQR 18-36), ventilation scores were from 0/16-11/16 (median 4, IQR 2-6), and PPE scores were from 3/16-15/16 (median 9, IQR 7-11). None of the health facilities met the criteria for acceptable HealthWISE score, and $42 \%$ had an unacceptable HealthWISE score of below $50 \%$.

The results of the logistic regression analysis assessing the availability of a provincial policy and hospital preparedness indicators showed that in the adjusted model, PPE and ventilation score were statistically associated with the availability of a COVID-19 provincial policy (Table 6). The presence or implementation of the provincial policy was associated with an increase in PPE score.

\section{Hospital staff infection rate and compliance score}

From March 5, 2020 to June 15, 2020, the cumulative hospital infection rate for COVID-19 at the 45 facilities ranged from $0-17.9 \%$, with a median $0.3 \%$ infection rate (IQR: $0.0-0.9 \%)$. We applied nonparametric statistical tests because the data seemed non-normal (Shapiro-Wilk test : $p<0.001$ ). We further adjusted by the total number of employees given that plotting infection rate against compliance score showed there might be some clustering by province (Fig. 1).

We classified each hospital into two categories: lower compliance or higher compliance, using the median score (42) to determine categories (Fig. 2). The lower compliance group (with a score <42) had a median infection rate of $0.75 \%$, and the higher compliance group (with score $\geq 42$ ) had a median infection rate of $0.1 \%$. While the infection rate is low for both groups, the Mann-Whitney $U$ test suggested a significant difference between the medians of the two groups. Our adjusted Poisson Regression estimated an incidence rate ratio of 0.98 (95\% Confidence Interval: $0.97,0.98)$ for higher compliance vs. lower compliance.

\section{Discussion}

When we conducted our study, the SARS-CoV-2 epidemic was still moving towards its peak with at least 106108 cases and the epidemic curve still rising sharply in South Africa [29, 30]. The national data indicated SARS-CoV-2 cases clustering among health workers in some health facilities, a phenomenon that was expected with plans to contain it.

Our PAR conducted early in the pandemic aimed to assess the OSH system for health worker's readiness for SARS-CoV-2; and to assess health facilities for the protection of health workers against SARS-CoV-2 infection with reference to the principles of the ILO/WHO joint HealthWISE tool. There was a clear discrepancy in the availability of resources for OSH systems and their readiness for SARS-Cov-2 in the four PDoH. The Province A, which is in the economic hub of South Africa, was more prepared and had more resources compared to the other three PDoHs, which are mostly rural.

While only Province A and D already had a policy on SARS-CoV-2 in healthcare, all the PDoH reported having health plans for protecting health workers from SARS-CoV-2. This finding is consistent with 
studies examining TB IPC for health workers where it was found that South Africa had IPC policies but lacks in implementation [31, 32]. It was not surprising that Province A, had an allocated budget for the protection of health workers from SARS-CoV-2, as it generally more resources than other PDoH in South Africa[33]. However, it was unexpected for Province $D$, since it is generally a poorly resourced PDoH with limited human resources for OSH; particularly occupational medical and nursing professionals. While of serious concern, it was not surprising that only Province A had an occupational medical practitioner driving the programme at provincial level. Province $B$ had occupational health nursing support at a provincial level, which is common in South Africa, hence it was troubling that the Province $C$ had no medical or nursing support. This lack of occupational health trained personnel at provincial level to assist in planning and managing the OSH system for health workers in the fight against SARS-CoV-2 suggested to the authors that major gaps may exist in the protection of health workers. While IPC nurses be present in the health system, they did not play an active role at a provincial or facility level in protecting the health of health workers, their role was around general IPC for the patients in main. It was however, a more pressing emergency in Province $C$ that they did not have any of the essential human resources for the fight against SARS-CoV-2 and or even OSH in general. This shortage of OSH professionals not only in Province $\mathrm{C}$ but also in Province B and D may constitute an obstacle to the provision of OSH services [26].

Since our PAR was conducted in the early stages of the epidemic, we hoped to check if the PDoHs were prioritizing primary prevention and we were disappointed to learn that only one PDoH had carried out the health risk assessments and two had procured PPE. While the South African National Department of Health had issued a directive for health workers to receive the influenza vaccine, only Province D PDoH had started offering its health workers influenza vaccinations. All the PDoH reported providing education and training, albeit general SARS-CoV-2 information. There was some information related to the public health and IPC response that was similar for OSH. It was impressive that three of the PDoH were providing screening and testing, treatment and mental health services for their health workers.

Overall, Province A, B and D had some elements of an OSH system that were activated to protect the health workers. While our PAR was targeted at assessing the OSH system readiness for SARS-CoV-2 in $\mathrm{PDoH}$, it has been able to identify the coverage of OSH for health workers in line with calls from numerous sources including the United Nations Resolution on Sustainable Development Goals[34, 35]. As shown by Rantanen et al [26], our study identified that all the assessed PDoH had some OSH systems coverage albeit of varying coverage and resources between the PDoH, with Province A PDoH being the most resourced and Province $C$ the least resourced. Our study further confirms the importance of having a health policy in place for health interventions, as shown by the fact that the odds of having an acceptable PPE score were $72 \%$ if the PDoH had a SARS-CoV-2 policy for health workers.

Our research team has previously trained health workers in South Africa, particularly in Province A and B on the use of HealthWISE [18, 22]; Using an adapted HealthWISE checklist health workers and health facility managers identified SARS-CoV-2 IPC measures. Based on the participants in the HealthWISE, our research showed that in South Africa, $\mathrm{OSH}$ for health workers was occupational health nurse driven and with a large number of environmental health practitioners supporting at health facilities, with a

Page 12/30 
significantly low number of occupational medical practitioners. It was concerning for the research team to find that only about half of assessed health facilities had IPC nurses. We were encouraged by the participation of very senior health facility management including chief executives, medical managers and nursing matrons highlighting how seriously some health facilities were taking the SARS-CoV-2 epidemic; as well as their understanding and embracing the HealthWISE way of doing OSH.

Our HealthWISE adapted checklist concentrated in some key areas of the health facilities to provide a snapshot of what health workers and managers needed to prioritize using limited resources. The research identified the health facility entrance as the main area of strategic importance for not only alerting and increasing health workers' OSH practice, but also for influencing their change of behavior under the new normal of SARS-CoV-2. Overall, the checklist indicated that health facilities had not identified and actively prepared their health facilities to protect health workers, patients and visitors from SARS-CoV-2. The fact that none of the assessed health facilities attained the acceptable HealthWISE score of $\geq 75 \%$ was concerning, highlighting the need for increased effort to protect the health of health workers. This poor performance also highlighted the importance of a pragmatic tool, such as HealthWISE, which can be utilized by all health workers in order to monitor and evaluate the performance of their OSH in their workplace without the need for highly specialized professionals. During the HealthWISE assessments, we encountered a wide range of IPC and OSH practices from non-existent to excessive measures between and within PDoH, even though South Africa has produced national IPC guidelines for health settings [36]. Finally, our analysis of the relationship between OSH compliance and infection rates in health workers showed that those facilities with a score above the median had a reduced risk compared to those below the median, which suggests that facilities should aim to improve their score even when small improvements do not lead to an acceptable level of compliance.

Overall, we found that a health policy is essential for the implementation of an OSH programme for health workers and that the HealthWISE approach to assessing health facilities' IPC and OSH readiness for SARS-CoV-2, was very useful for health workers and management without formal training in both IPC and OSH. It also allowed for a more open, non-threatening and acceptable way of bringing about change as the managers and health workers were able to identify gaps and recommend feasible interventions often at no cost or within reasonable cost to both the PDoH and health facility.

\section{Conclusions}

While South Africa is an upper-middle-income country, there are vast differences in the resources for health between and within PDoH. Our study was able to show these differences, with one province proving to have abundant OSH resources, two provinces having some resources, while one province was severely under-resourced in terms of IPC and OSH. Our timely assessment of the OSH system for SARSCoV-2 also highlighted the variability in coverage and services between and within PDoH, and allowed for timely alerts to the relevant authorities so that appropriate interventional steps could be undertaken. At a health facility level, the role of managers and health workers collaborating in improving the IPC and OSH measures using the HealthWISE approach proved to be an acceptable and appreciated method. It would 
be valuable to assess how regular application of such self-assessment methods can and do stimulate improvement in the processes of providing protection and in producing improved results as the COVID-19 and other health risks endure.

\section{List Of Abbreviations}

COVID-19

Coronavirus disease 19; OSH:occupational safety and health; SARS-CoV-2:severe acute respiratory syndrome coronavirus 2; WHO:World Health Organization

\section{Declarations}

\section{Ethical approval and consent to participate}

This study was one component of the research project 'A rapid appraisal of the COVID-19 OHS response by four provinces in South Africa'. The methods for the study were approved by the Faculty of Health Sciences Research Ethics Committee, University of Pretoria, South Africa (Ethics Reference Number: 246/2020). Formal written informed consent was not sought from participants in this component of the research project as indicated in the methods submitted and approved by the Faculty of Health Sciences Research Ethics Committee, University of Pretoria, South Africa (Ethics Reference Number: 246/2020). As the data collected were part of the preparation of the COVID-19 response in the respective PDoHs, it was originally primarily collected for operational use, as part of the operational oversight responsibilities of some of the members of the research team. The health workers who participated were doing so as an extension of their normal work; they were briefed about the objectives of the project and verbal individual informed consent was obtained for data collection, ensuring participants that confidentiality would be maintained and only aggregated and anonymized results would be shared.

Although the work was originally intended for operational research, the researchers later recognized the potential here to inform world knowledge and therefore sought and obtained permission from the PDoHs to publish the results of the operational data anonymously, in keeping with the undertakings to participants. All protocols were carried out in accordance with relevant guidelines and regulations of the South African Department of Health as agreed with the respective PDoHs[37].

\section{Consent for publication}

Not applicable.

\section{Availability of data and materials}

The datasets used and analyzed during the current study are available from the corresponding author on request.

\section{Competing Interests}


The authors declare that they have no competing interests.

\section{Funding}

Funding for the research was obtained from the University of Pretoria - University of Leeds "COVID-19 Rapid Response Innovation Fund" (Project 4) and Canadian Institutes of Health Research COVID-19 Rapid Research - Social Policy and Public Health Responses.

\section{Author Contributions}

"Conceptualization, M.Z.; Data curation, M.Z., M.M., J.R., N.T., N.M., S.M. and N.C., Formal analysis, M.Z., M.M., J.R., N.T., N.M., S.M. and N.C.; Funding acquisition, K.V., M.Z., S.M. and N.C.; Investigation, M.Z., M.M., J.R., N.T., N.M., S.M., N.C., J.S., A.Y., E.W., and J.R.; Methodology, M.Z., S.M., N.C., N.M. and K.V.; Project administration, M.Z. and K.V.; Resources, K.V., M.Z., S.M. and N.C.; Supervision, M.Z.; Visualization, M.Z., M.M.; Writing - original draft, M.Z.; Writing - review \& editing, M.Z., K.V, M.M., J.R., N.T., N.M., S.M., N.C., A.Y., E.W., and J.S. All authors reviewed the manuscript".

\section{Acknowledgments}

The authors are grateful to the management of the four participating Provincial Departments of Health, the occupational health coordinators in the respective PDoHs (Ms Sagwadi Chauke, Dr Tumiso Malatji, Ms Patricia Moloi, Ms Connie Ratseane and Dr Sipho Senabe), management of the participating facilities, and all the health workers who participated. We would like to acknowledge the University of Pretoria's School of Health Systems and Public Health, the University of Leeds, the National Health Laboratory Service and the National Institute for Occupational Health for their contributions in supporting the research. Finally, we appreciate the support of Stephen Barker in our incidence rate ratio analysis.

\section{References}

1. Coronavirus Disease (COVID-19) - events as they happen [https://www.who.int/emergencies/diseases/novel-coronavirus-2019/events-as-they-happen]

2. WHO Director-General's opening remarks at the media briefing on COVID-19-11 March 2020 [https://www.who.int/dg/speeches/detail/who-director-general-s-opening-remarks-at-the-mediabriefing-on-covid-19--11-march-2020]

3. WHO Coronavirus Disease (COVID-19) Dashboard [https://covid19.who.int]

4. COVID-19 Surveillance [https://www.nicd.ac.za/]

5. National Institute for Occupational Health COVID-19 Sentinel Hospital Surveillance Weekly Update on Hospitalized HCWs. In: COVID-19 Sentinel Surveillance on Hospitalized Health Care Workers (HCW). Edited by NIOH. Johannesburg (South Africa): $\mathrm{NIOH} ; 2021$.

6. Lan F-Y, Wei C-F, Hsu Y-T, Christiani DC, Kales SN: Work-related COVID-19 transmission in six Asian countries/areas: A follow-up study. PloS one 2020, 15(5):e0233588. 
7. WHO I Health workers [https://www.who.int/occupational_health/topics/hcworkers/en/]

8. Chowell G, Abdirizak F, Lee S, Lee J, Jung E, Nishiura H, Viboud C: Transmission characteristics of MERS and SARS in the healthcare setting: a comparative study. BMC Medicine 2015, 13(1):210.

9. Chou R, Dana T, Buckley DI, Selph S, Fu R, Totten AM: Epidemiology of and risk factors for coronavirus infection in health care workers: a living rapid review. Annals of internal medicine 2020.

10. Canova V, Lederer Schläpfer H, Piso RJ, Droll A, Fenner L, Hoffmann T, Hoffmann M: Transmission risk of SARS-CoV-2 to healthcare workers -observational results of a primary care hospital contact tracing. Swiss Med Wkly 2020, 150:w20257.

11. Folgueira MD, Munoz-Ruiperez C, Alonso-Lopez MA, Delgado R: SARS-CoV-2 infection in Health Care Workers in a large public hospital in Madrid, Spain, during March 2020. medRxiv 2020:2020.2004.2007.20055723.

12. Prevention CCfDCa: The Epidemiological Characteristics of an Outbreak of 2019 Novel Coronavirus Diseases (COVID-19) - China, 2020. In., vol. 2020. Beijing (China): CCDC; 2020.

13. Nguyen LH, Drew DA, Graham MS, Joshi AD, Guo C-G, Ma W, Mehta RS, Warner ET, Sikavi DR, Lo C-H et al: Risk of COVID-19 among front-line health-care workers and the general community: a prospective cohort study. The Lancet Public Health 2020, 5(9):e475-e483.

14. Ran L, Chen X, Wang Y, Wu W, Zhang L, Tan X: Risk Factors of Healthcare Workers with Corona Virus Disease 2019: A Retrospective Cohort Study in a Designated Hospital of Wuhan in China. Clinical Infectious Diseases 2020.

15. Word Health Organization MONITORING THE BUILDING BLOCKS OF HEALTH SYSTEMS: A HANDBOOK OF INDICATORS AND THEIR MEASUREMENT STRATEGIES. In.: WHO; 2010.

16. Health workforce [https://www.who.int/health-topics/health-workforce\#tab=tab_1]

17. Word Health Organization HEALTH WORKFORCE REQUIREMENTS FOR UNIVERSAL HEALTH COVERAGE AND THE SUSTAINABLE DEVELOPMENT GOALS. In: Human Resources for Health Observer Series. vol. 17: WHO; 2020.

18. HealthWISE - Work Improvement in Health Services [https://www.ilo.org/sector/Resources/trainingmaterials/WCMS_250540/lang-en/index.htm]

19. National Department of Health National Health Act 61 of 2003 | South African Government. In., vol. 61 of 2003. Pretoria (South Africa): NDoH; 2003.

20. Manyazewal $\mathrm{T}$ : Using the World Health Organization health system building blocks through survey of healthcare professionals to determine the performance of public healthcare facilities. Archives of Public Health 2017, 75(1):50.

21. Republic of South Africa Occupational Health and Safety Act 85 of 1993. In. Edited by Department of Employment and Labour Pretoria (South Africa): Government Gazette; 1993.

22. Wilcox ES, Chimedza IT, Mabhele S, Romao P, Spiegel JM, Zungu M, Yassi A: Empowering Health Workers to Protect Their Own Health: A Study of Enabling Factors and Barriers to Implementing 
HealthWISE in Mozambique, South Africa, and Zimbabwe. International journal of environmental research and public health 2020, 17(12).

23. Baum F, MacDougall C, Smith D: Participatory action research. Journal of epidemiology and community health 2006, 60(10):854-857.

24. Moodley SV, Zungu M, Malotle M, Voyi K, Claassen N, Ramodike J, Thunzi N, Mlangeni N: A health worker knowledge, attitudes and practices survey of SARS-CoV-2 infection prevention and control in South Africa. BMC Infectious Diseases 2021, 21(1):138.

25. Convention C161 - Occupational Health Services Convention, 1985 (No. 161) [https://www.ilo.org/dyn/normlex/en/f? p=NORMLEXPUB:12100:0::NO:12100:P12100_INSTRUMENT_ID:312306:NO]

26. Rantanen J, Lehtinen S, Valenti A, lavicoli S: A global survey on occupational health services in selected international commission on occupational health (ICOH) member countries. BMC public health 2017, 17(1):787.

27. Jensen PA, Lambert LA, lademarco MF, Ridzon R: Guidelines for preventing the transmission of Mycobacterium tuberculosis in health-care settings, 2005. 2005.

28. Hierachy of controls [https://www.cdc.gov/niosh/topics/hierarchy/default.html]

29. Update on Covid-19 (23rd June 2020) [https://sacoronavirus.co.za/2020/06/23/update-on-covid-1923rd-june-2020/]

30. South Africa Coronavirus: 106,108 Cases and 2,102 Deaths - Worldometer [https://www.worldometers.info/coronavirus/country/south-africa/]

31. Malotle MM, Spiegel JM, Yassi A, Ngubeni D, O'Hara LM, Adu PA, Bryce EA, Mlangeni N, Gemell GSM, Zungu M: Occupational tuberculosis in South Africa: are health care workers adequately protected? Public Health Action 2017, 7(4):258-267.

32. National Department of Health National tuberculosis management guidelines. In. Pretoria, South Africa: NDoH; 2014.

33. UNICEF South Africa Health Budget South Africa 2017/2018. In: Health Budget South Africa. Edited by Africa US. Pretoria (South Africa): UNICEF; 2018.

34. Sustainable Development Goals: 17 goals to transform our world. [https://www.un.org/sustainabledevelopment/development-agenda/]

35. Word Health Organization WHA Resolution 60.26. Global Plan of Action on Workers' Health 20082017. In. Geneva (Switzerland): WHO; 2007.

36. National Department of Health COVID-19 Disease: Infection Prevention and Control Guidelines Version. In. Pretoria, South Africa: NDoH; 2020.

37. National Department of Health Ethics in Health Research: Principles, processes and structures. 2015.

\section{Tables}


Table 1

Overall main entrance HealthWISE walkthrough assessment findings

Main pedestrian and vehicle entrance to the health facility

\begin{tabular}{|c|c|c|c|c|}
\hline $\begin{array}{l}\text { Prevention } \\
\text { Measures }\end{array}$ & Question & Adequate & $\begin{array}{l}\text { Requires } \\
\text { improvement }\end{array}$ & Comments \\
\hline \multirow[t]{2}{*}{ Ventilation } & $\begin{array}{l}\text { Is outdoor } \\
\text { ventilation } \\
\text { adequate? }\end{array}$ & Yes & No & $\begin{array}{l}\text { All outdoor entrances had good } \\
\text { natural ventilation. }\end{array}$ \\
\hline & $\begin{array}{l}\text { IS indoor } \\
\text { ventilation } \\
\text { adequate? }\end{array}$ & No & Yes & $\begin{array}{l}\text { No mechanical ventilation, windows } \\
\& \text { doors not open. }\end{array}$ \\
\hline \multirow[t]{8}{*}{$\begin{array}{l}\text { Administrative } \\
\text { measures }\end{array}$} & $\begin{array}{l}\text { Are patients } \\
\text { social } \\
\text { distancing? }\end{array}$ & No & Yes & $\begin{array}{l}\text { Majority of staff not social } \\
\text { distancing }\end{array}$ \\
\hline & $\begin{array}{l}\text { Are staff } \\
\text { social } \\
\text { distancing? }\end{array}$ & No & Yes & $\begin{array}{l}\text { In the bigger facilities there were } \\
\text { more security guards at the gate and } \\
\text { there was lower likelihood of no } \\
\text { social distancing. }\end{array}$ \\
\hline & $\begin{array}{l}\text { Are there } \\
\text { markings for } \\
\text { social } \\
\text { distancing? }\end{array}$ & No & Yes & $\begin{array}{l}\text { There were limited markings for } \\
\text { social distancing }\end{array}$ \\
\hline & $\begin{array}{l}\text { Is furniture } \\
\text { positioned } \\
\text { for social } \\
\text { distancing? }\end{array}$ & No & Yes & $\begin{array}{l}\text { There was no rearrangement of } \\
\text { furniture to allow for social } \\
\text { distancing even when space allows }\end{array}$ \\
\hline & $\begin{array}{l}\text { Are there } \\
\text { posters or } \\
\text { information } \\
\text { leaflets } \\
\text { about } \\
\text { COVID-19? }\end{array}$ & No & Yes & $\begin{array}{l}\text { There were few COVID- } 19 \text { posters in } \\
\text { most of the facilities across the } \\
\text { PDoH and when present did not } \\
\text { address health workers but patients.. }\end{array}$ \\
\hline & $\begin{array}{l}\text { Is there an } \\
\text { area with } \\
\text { water and } \\
\text { soap to } \\
\text { clean hands? }\end{array}$ & Yes & No & $\begin{array}{l}\text { Lack of water basin and soap in } \\
\text { certain areas particularly Province A } \\
\text { was an issue but overall there was } \\
\text { water and soap. }\end{array}$ \\
\hline & $\begin{array}{l}\text { Are there } \\
\text { hand } \\
\text { sanitizers in } \\
\text { all entrances } \\
\text { and exit } \\
\text { points? }\end{array}$ & Yes & No & $\begin{array}{l}\text { There seems to be huge investment } \\
\text { in hand sanitizers }\end{array}$ \\
\hline & $\begin{array}{l}\text { Is waste } \\
\text { properly } \\
\text { segregated? }\end{array}$ & No & Yes & $\begin{array}{l}\text { Majority of the facilities only had } \\
\text { general waste bins and were not } \\
\text { prepared for medical waste (SARS- } \\
\text { CoV-2). }\end{array}$ \\
\hline
\end{tabular}




\begin{tabular}{|c|c|c|c|c|}
\hline \multicolumn{5}{|c|}{ Main pedestrian and vehicle entrance to the health facility } \\
\hline & $\begin{array}{l}\text { Are COVID- } \\
19 \text { waste } \\
\text { management } \\
\text { boxes }\end{array}$ & No & Yes & $\begin{array}{l}\text { This was almost non-existent in the } \\
\text { majority of facilities. }\end{array}$ \\
\hline \multirow[t]{4}{*}{$\begin{array}{l}\text { Personal } \\
\text { Protective } \\
\text { Equipment }\end{array}$} & $\begin{array}{l}\text { Are workers } \\
\text { wearing } \\
\text { appropriate } \\
\text { PPE? }\end{array}$ & No & Yes & $\begin{array}{l}\text { At the entrance of the facility we } \\
\text { expected surgical masks but majority } \\
\text { of personnel were wearing cloth } \\
\text { masks. There were also a few health } \\
\text { workers who were wearing cloth } \\
\text { mask inside the hospital. Since PPE } \\
\text { is critical for this pandemic and } \\
\text { investments have been huge, the } \\
\text { facilities should train workers and } \\
\text { supply appropriate PPE }\end{array}$ \\
\hline & $\begin{array}{l}\text { Are they } \\
\text { wearing PPE } \\
\text { correctly? }\end{array}$ & No & Yes & $\begin{array}{l}\text { The surgical mask was sometimes } \\
\text { below the nose and not covering both } \\
\text { mouth and nose }\end{array}$ \\
\hline & $\begin{array}{l}\text { Are the staff } \\
\text { wearing the } \\
\text { same clothes } \\
\text { from home, } \\
\text { during work } \\
\text { and back } \\
\text { home? }\end{array}$ & No & Yes & $\begin{array}{l}\text { Since the carrier rate of the SARS- } \\
\text { CoV-2 on clothing, it is advisable that } \\
\text { health workers change clothes to } \\
\text { PPE on arrival and when departing } \\
\text { work. }\end{array}$ \\
\hline & $\begin{array}{l}\text { Do you think } \\
\text { there is } \\
\text { adequate } \\
\text { PPE? }\end{array}$ & Yes & No & $\begin{array}{l}\text { Generally, there was some form of } \\
\text { PPE available }\end{array}$ \\
\hline
\end{tabular}


Table 2

Overall Accident and Emergency area HealthWISE walkthrough assessment findings

\section{Accident and Emergency Department}

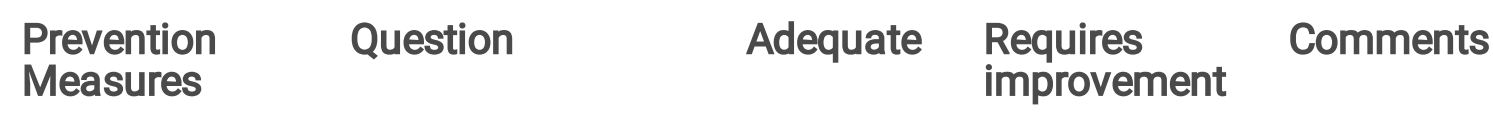

$\begin{array}{llll}\text { Ventilation Is ventilation } \quad \text { No } & \text { Yes } & \begin{array}{l}\text { Poor culture of opening the } \\ \text { windows, lack of or broken } \\ \text { mechanical ventilation }\end{array}\end{array}$

$\begin{array}{llll}\begin{array}{l}\text { Administrative } \\ \text { measures }\end{array} & \begin{array}{l}\text { Are patients } \\ \text { social distancing? }\end{array} & \text { Yes } \quad \text { No } & \begin{array}{l}\text { Most of the facilities have } \\ \text { provisions for patients social } \\ \text { distancing such as markings } \\ \text { and queue marshals. }\end{array}\end{array}$

$\begin{array}{lll}\text { Is staff social } \quad \text { No } \quad \text { Yes } & \begin{array}{l}\text { Majority of the staff were not } \\ \text { practicing social distancing } \\ \text { distancing? }\end{array} \\ & \\ & \text { particularly when they were in } \\ & \text { their workstations, there is a } \\ \text { space shortage }\end{array}$

Are there No Yes

markings for

Yes

Inside the area there was a social distancing? considerable number of institutions without markings for social distancing in their accident and emergency area.

\begin{tabular}{|c|c|c|c|}
\hline $\begin{array}{l}\text { Is furniture } \\
\text { positioned for } \\
\text { social distancing? }\end{array}$ & No & No & $\begin{array}{l}\text { There was no rearrangement of } \\
\text { furniture to allow for social } \\
\text { distancing mostly due to lack of } \\
\text { space. }\end{array}$ \\
\hline
\end{tabular}

Are the posters or No Yes Majority of the facilities have information few and poor quality Covid-19 leaflets about posters and very few facilities COVID-19? have posters that addresses $\mathrm{OSH}$ of HWs against Covid-19

Is there an area Yes No
with water and that did not have water, it was a soap to clean municipality issue of a water hands? outage in the whole municipality during the walk through

Are there hand No Nos
sanitizers in all
entrances and
exit points?

Some accident and emergency departments did not have visible hand sanitizers in their entrances or exits. One of the challenges mentioned was to put them in the strategic positions e.g. entrances and exit points

Is waste properly Yes No segregated? 


\begin{tabular}{|c|c|c|c|c|}
\hline \multicolumn{5}{|c|}{ Accident and Emergency Department } \\
\hline & $\begin{array}{l}\text { Are COVID-19 } \\
\text { waste } \\
\text { management } \\
\text { boxes? }\end{array}$ & Yes & No & \\
\hline \multirow[t]{4}{*}{$\begin{array}{l}\text { Personal } \\
\text { Protective } \\
\text { Equipment }\end{array}$} & $\begin{array}{l}\text { Are workers } \\
\text { wearing } \\
\text { appropriate PPE? }\end{array}$ & Yes & Yes & $\begin{array}{l}\text { There were those few health } \\
\text { workers that were not wearing } \\
\text { appropriate PPEs e.g. cloth } \\
\text { masks in accident and } \\
\text { emergency }\end{array}$ \\
\hline & $\begin{array}{l}\text { Are workers } \\
\text { wearing PPE } \\
\text { correctly? }\end{array}$ & No & Yes & $\begin{array}{l}\text { The surgical mask were } \\
\text { sometimes below the nose }\end{array}$ \\
\hline & $\begin{array}{l}\text { Are the staff } \\
\text { wearing the same } \\
\text { clothes from } \\
\text { home, during } \\
\text { work and back } \\
\text { home? }\end{array}$ & No & Yes & $\begin{array}{l}\text { Since the carrier rate of the } \\
\text { SARS-CoV-2 on clothing, it is } \\
\text { advisable that health workers } \\
\text { change clothes to PPE on arrival } \\
\text { and when departing work. }\end{array}$ \\
\hline & $\begin{array}{l}\text { Do you think there } \\
\text { was adequate } \\
\text { PPE? }\end{array}$ & Yes & No & $\begin{array}{l}\text { Generally, there was some form } \\
\text { of PPE available }\end{array}$ \\
\hline
\end{tabular}


Table 3

Overall Outpatient Department HealthWISE walkthrough assessment findings

\section{Outpatient Department}

\begin{tabular}{|c|c|c|c|}
\hline $\begin{array}{l}\text { Prevention } \\
\text { Measures }\end{array}$ & Question & Adequate & $\begin{array}{l}\text { Requires } \\
\text { improvement }\end{array}$ \\
\hline
\end{tabular}

$\begin{array}{lll}\text { Ventilation Is ventilation } \quad \text { No } & \text { Yes } \\ \text { adequate? }\end{array}$

The majority of the Province A facilities required a lot of improvement, there was no natural or mechanical ventilation

$\begin{array}{llll}\begin{array}{l}\text { Administrative } \\ \text { measures }\end{array} & \begin{array}{l}\text { Are patients } \\ \text { social distancing? }\end{array} & \text { Yes } & \text { No }\end{array}$

Very few facilities were not ensuring that patients are observing social distancing. A few health facilities were using queue marshals to control social distancing.

Are staff social No Nes
distancing?

Health workers concentrated around administrative desks to write notes, use telephone, complete forms, and even socialize. Small or lack of dining and rest areas contributed.

\begin{tabular}{|c|c|c|c|}
\hline $\begin{array}{l}\text { Are there } \\
\text { markings for } \\
\text { social distancinq? }\end{array}$ & No & Yes & $\begin{array}{l}\text { These were lacking in most } \\
\text { OPDs }\end{array}$ \\
\hline
\end{tabular}

Is furniture $\quad$ No $\quad$ Yes
positioned for
social distancing?

Some hospitals had not rearranged the furniture for social distancing as the distance between the furniture was the same as before the Covid-19 pandemic, but some did not have space to change arrangement

Are the posters or No $\quad$ Yes
information
leaflets about
COVID-19?

A few of the facilities had COVID-19 posters but they did not indicate how health workers can protect themselves and they were of poor quality

Is there an area Yes No with water and soap to clean hands?

With regards to the few facilities that did not have water, it was a municipality issue of a water outage in the whole municipality during the walk through

Are there hand $\quad$ Yes $\quad$ No
sanitizers in all
entrances and exit
points?




\begin{tabular}{|c|c|c|c|c|}
\hline \multicolumn{5}{|c|}{ Outpatient Department } \\
\hline & $\begin{array}{l}\text { Is waste properly } \\
\text { segregated? }\end{array}$ & Yes & No & \\
\hline & $\begin{array}{l}\text { Are COVID-19 } \\
\text { waste } \\
\text { management } \\
\text { boxes present }\end{array}$ & Yes & No & \\
\hline \multirow[t]{4}{*}{$\begin{array}{l}\text { Personal } \\
\text { Protective } \\
\text { Equipment }\end{array}$} & $\begin{array}{l}\text { Are workers } \\
\text { wearing } \\
\text { appropriate PPE? }\end{array}$ & Yes & No & \\
\hline & $\begin{array}{l}\text { Are they wearing } \\
\text { PPE correctly? }\end{array}$ & No & Yes & $\begin{array}{l}\text { The surgical mask was } \\
\text { sometimes below the nose }\end{array}$ \\
\hline & $\begin{array}{l}\text { Are the staff } \\
\text { wearing the same } \\
\text { clothes from } \\
\text { home, during } \\
\text { work and back } \\
\text { home? }\end{array}$ & No & Yes & $\begin{array}{l}\text { Since the carrier rate of the } \\
\text { SARS-CoV-2 on clothing, it is } \\
\text { advisable that health workers } \\
\text { change clothes to PPE on arrival } \\
\text { and when departing work. }\end{array}$ \\
\hline & $\begin{array}{l}\text { Do you think there } \\
\text { was adequate } \\
\text { PPE }\end{array}$ & Yes & No & $\begin{array}{l}\text { Generally there was some form } \\
\text { of PPE available }\end{array}$ \\
\hline
\end{tabular}


Table 4

Overall SARS-CoV-2 dedicated wards for suspected and confirmed patients HealthWISE walkthrough assessment findings

\section{SARS-CoV-2 dedicated wards for suspected and confirmed patients}

$\begin{array}{llll}\begin{array}{l}\text { Prevention } \\ \text { Measures }\end{array} & \text { Question } & \text { Adequate } & \begin{array}{l}\text { Requires } \\ \text { improvement }\end{array}\end{array}$ Comments

\begin{tabular}{|c|c|c|c|c|}
\hline Ventilation & $\begin{array}{l}\text { Is ventilation } \\
\text { adequate? }\end{array}$ & Yes & Yes & $\begin{array}{l}\text { Some of the Province A } \\
\text { facilities need significant } \\
\text { improvements }\end{array}$ \\
\hline
\end{tabular}

\begin{tabular}{|c|c|c|c|c|}
\hline $\begin{array}{l}\text { Administrative } \\
\text { measures }\end{array}$ & $\begin{array}{l}\text { Are patients social } \\
\text { distancing? }\end{array}$ & Yes & No & $\begin{array}{l}\text { All of the patients under } \\
\text { investigation were } \\
\text { practicing social distancing }\end{array}$ \\
\hline & $\begin{array}{l}\text { Is staff social } \\
\text { distancing? }\end{array}$ & No & Yes & $\begin{array}{l}\text { Particularly during rest } \\
\text { periods and when doing } \\
\text { administrative work }\end{array}$ \\
\hline
\end{tabular}

\begin{tabular}{|c|c|c|c|c|}
\hline & $\begin{array}{l}\text { Is furniture positioned } \\
\text { for social distancing? }\end{array}$ & Yes & No & \\
\hline & $\begin{array}{l}\text { Are there posters or } \\
\text { information leaflets } \\
\text { about COVID-19? }\end{array}$ & No & Yes & $\begin{array}{l}\text { Few of the facilities had } \\
\text { COVID- } 19 \text { posters but they } \\
\text { did not indicate how health } \\
\text { workers can protect } \\
\text { themselves and they were } \\
\text { of poor quality. }\end{array}$ \\
\hline & $\begin{array}{l}\text { Is there an area with } \\
\text { water and soap to } \\
\text { clean hands? }\end{array}$ & Yes & No & $\begin{array}{l}\text { During the walkthrough, one } \\
\text { facility in Province B did not } \\
\text { have water as there was } \\
\text { water outage in the whole } \\
\text { town. }\end{array}$ \\
\hline & $\begin{array}{l}\text { Are there hand } \\
\text { sanitizers at all } \\
\text { entrances and exit } \\
\text { points? }\end{array}$ & Yes & No & \\
\hline & $\begin{array}{l}\text { Is waste properly } \\
\text { segregated? }\end{array}$ & Yes & No & \\
\hline & $\begin{array}{l}\text { Are COVID-19 waste } \\
\text { management boxes } \\
\text { present }\end{array}$ & Yes & No & \\
\hline \multirow[t]{2}{*}{$\begin{array}{l}\text { Personal } \\
\text { Protective } \\
\text { Equipment }\end{array}$} & $\begin{array}{l}\text { Are workers wearing } \\
\text { appropriate PPE? }\end{array}$ & Yes & No & \\
\hline & $\begin{array}{l}\text { Are they wearing PPE } \\
\text { correctly? }\end{array}$ & Yes & No & \\
\hline
\end{tabular}


SARS-CoV-2 dedicated wards for suspected and confirmed patients

Is the staff wearing

No

Yes

In a few facilities health

same clothes from workers were wearing their home, during work and back home? uniform, with some form of PPE on top 
Table 5

HealthWISE compliance scores

\begin{tabular}{|c|c|c|c|c|c|c|}
\hline Province & Hospital & $\begin{array}{l}\text { Ventilation } \\
\text { score (16) }\end{array}$ & $\begin{array}{l}\text { Administrative } \\
\text { score (56) }\end{array}$ & $\begin{array}{l}\text { PPE } \\
\text { score } \\
(16)\end{array}$ & $\begin{array}{l}\text { Total } \\
\text { Score } \\
(88)\end{array}$ & $\begin{array}{l}\text { Acceptable } \\
\text { compliance (> } \\
75 \%)\end{array}$ \\
\hline \multirow{9}{*}{$\begin{array}{l}\text { Province } \\
\text { A }\end{array}$} & PA 1 & 11 & 24 & 10 & 45 & No $=52,3 \%$ \\
\hline & PA 2 & 0 & 16 & 6 & 22 & $\mathrm{No}=25,6 \%$ \\
\hline & PA 3 & 4 & 41 & 11 & 56 & $\mathrm{No}=65,1 \%$ \\
\hline & PA 4 & 0 & 25 & 9 & 34 & No $=39,5 \%$ \\
\hline & PA 5 & 0 & 35 & 10 & 45 & $\mathrm{No}=52,3 \%$ \\
\hline & PA 6 & 0 & 16 & 6 & 22 & $\mathrm{No}=25,6 \%$ \\
\hline & PA 7 & 2 & 8 & 10 & 20 & $\mathrm{No}=23,3 \%$ \\
\hline & PA 8 & 0 & 11 & 9 & 20 & $\mathrm{No}=23,3 \%$ \\
\hline & PA 9 & 2 & 6 & 10 & 18 & No $=20,9 \%$ \\
\hline \multirow{11}{*}{$\begin{array}{l}\text { Province } \\
\text { B }\end{array}$} & PB 1 & 4 & 37 & 8 & 49 & No $=57,0 \%$ \\
\hline & PB 2 & 9 & 34 & 8 & 51 & No $=59,0 \%$ \\
\hline & PB 3 & 5 & 37 & 11 & 53 & $\mathrm{No}=62,0 \%$ \\
\hline & PB 4 & 3 & 28 & 7 & 38 & $\mathrm{No}=59,0 \%$ \\
\hline & PB 5 & 4 & 26 & 8 & 38 & No $=59,0 \%$ \\
\hline & PB 6 & 11 & 43 & 10 & 64 & $\mathrm{No}=74,0 \%$ \\
\hline & PB 7 & 10 & 36 & 10 & 56 & $\mathrm{No}=66,0 \%$ \\
\hline & PB 8 & 8 & 37 & 10 & 55 & No $=64,0 \%$ \\
\hline & PB 9 & 7 & 36 & 9 & 52 & No $=60,0 \%$ \\
\hline & PB 10 & 6 & 35 & 9 & 50 & No $=58,0 \%$ \\
\hline & PB 11 & 5 & 10 & 7 & 22 & $\mathrm{No}=34,0 \%$ \\
\hline \multirow{4}{*}{$\begin{array}{l}\text { Province } \\
\text { C }\end{array}$} & PC 1 & 7 & 40 & 15 & 62 & No $=72,0 \%$ \\
\hline & PC 2 & 6 & 42 & 15 & 63 & No $=73,0 \%$ \\
\hline & PC 3 & 6 & 33 & 15 & 54 & $\mathrm{No}=63,0 \%$ \\
\hline & PC 4 & 6 & 30 & 15 & 51 & No $=59,0 \%$ \\
\hline
\end{tabular}

*an acceptable compliance score $\geq 75 \%$; compliance shading (green $=$ acceptable, orange $=$ requiring improvement, and red = unacceptable) 


\begin{tabular}{|c|c|c|c|c|c|c|}
\hline Province & Hospital & $\begin{array}{l}\text { Ventilation } \\
\text { score (16) }\end{array}$ & $\begin{array}{l}\text { Administrative } \\
\text { score (56) }\end{array}$ & $\begin{array}{l}\text { PPE } \\
\text { score } \\
(16)\end{array}$ & $\begin{array}{l}\text { Total } \\
\text { Score } \\
\text { (88) }\end{array}$ & $\begin{array}{l}\text { Acceptable } \\
\text { compliance (> } \\
75 \%)\end{array}$ \\
\hline & PC 5 & 6 & 46 & 11 & 63 & $\mathrm{No}=73,0 \%$ \\
\hline & PC 6 & 5 & 23 & 11 & 39 & $\mathrm{No}=45,0 \%$ \\
\hline & PC 7 & 5 & 36 & 15 & 56 & $\mathrm{No}=65,0 \%$ \\
\hline & PC 8 & 3 & 32 & 11 & 46 & $\mathrm{No}=53,0 \%$ \\
\hline & PC 9 & 5 & 42 & 11 & 58 & $\mathrm{No}=67,0 \%$ \\
\hline & PC 10 & 8 & 42 & 12 & 62 & $\mathrm{No}=72,0 \%$ \\
\hline \multirow{15}{*}{$\begin{array}{l}\text { Province } \\
\text { D }\end{array}$} & PD 1 & 5 & 17 & 7 & 29 & $\mathrm{No}=34,0 \%$ \\
\hline & PD 2 & 4 & 24 & 6 & 34 & $\mathrm{No}=53,0 \%$ \\
\hline & PD 3 & 7 & 20 & 9 & 36 & $\mathrm{No}=42,0 \%$ \\
\hline & PD 4 & 2 & 12 & 4 & 18 & $\mathrm{No}=43,0 \%$ \\
\hline & PD 5 & 4 & 21 & 7 & 32 & $\mathrm{No}=50,0 \%$ \\
\hline & PD 6 & 6 & 31 & 5 & 42 & $\mathrm{No}=49,0 \%$ \\
\hline & PD 7 & 3 & 12 & 7 & 22 & $\mathrm{No}=34,0 \%$ \\
\hline & PD 8 & 6 & 28 & 10 & 44 & $\mathrm{No}=51,0 \%$ \\
\hline & PD 9 & 4 & 23 & 9 & 36 & $\mathrm{No}=42,0 \%$ \\
\hline & PD 10 & 2 & 16 & 3 & 21 & $\mathrm{No}=50,0 \%$ \\
\hline & PD 11 & 2 & 10 & 4 & 16 & $\mathrm{No}=38,0 \%$ \\
\hline & PD 12 & 2 & 19 & 4 & 25 & $\mathrm{No}=60,0 \%$ \\
\hline & PD 13 & 3 & 28 & 10 & 41 & $\mathrm{No}=47,0 \%$ \\
\hline & PD 14 & 4 & 31 & 10 & 45 & $\mathrm{No}=52,0 \%$ \\
\hline & PD 15 & 1 & 9 & 4 & 14 & $\mathrm{No}=33,0 \%$ \\
\hline
\end{tabular}


Table 6

Logistic Regression model assessing the association between the Provincial Policy and indicators for hospital preparedness

\begin{tabular}{|lllll|}
\hline & Unadjusted Model & & Adjusted Model & \\
\hline Variables & Odds Ratio $(95 \% \mathrm{Cl})$ & P Value & Odds Ratio (95\% Cl) & P Value \\
\hline PPE Score & $1.02(0.94-1.10)$ & 0.601 & $1.72(1.25-2.38)$ & 0.001 \\
\hline Ventilation Score & $0.87(0.70-1.09)$ & 0.243 & $0.48(0.32-0.74)$ & 0.001 \\
\hline
\end{tabular}

Figures 


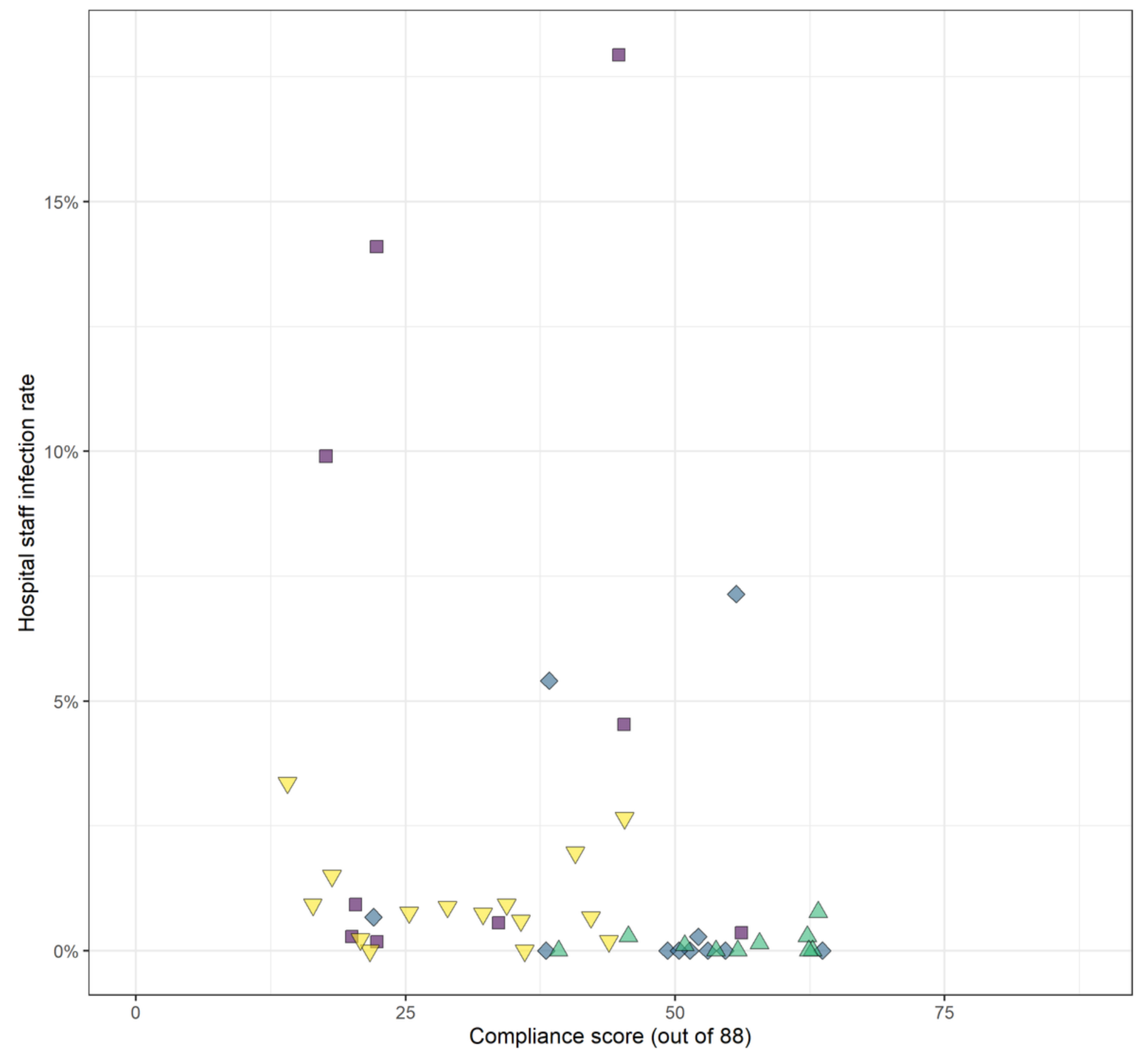

Province $\square$ Province A $\diamond$ Province B $\triangle$ Province $\mathrm{C} \nabla$ Province $\mathrm{D}$

\section{Figure 1}

Infection rate by the compliance score of each hospital, indicated by province 


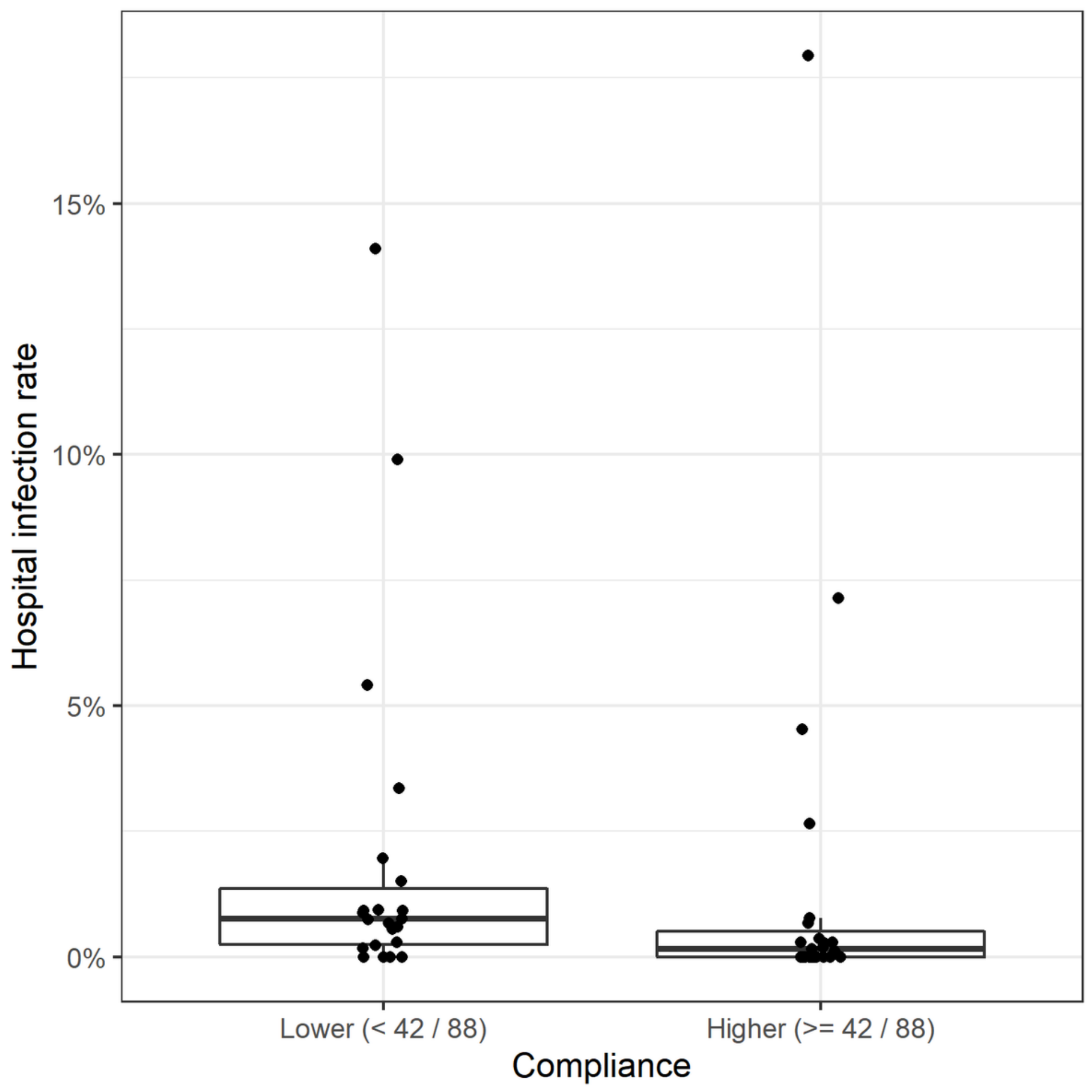

Figure 2

Box plot comparing lower and higher compliance hospital infection rates. Each point represents a hospital. The boxes show the IQR (25th to 75th percentile) with the bold horizontal line through the centre of the box showing the median 